New Zealand journal of industrial relations, 1987, 12, 81-87

\title{
Trends in official union membership : 1983 - 1985
}

\author{
Raymond Harbridge and Susan Webber*
}

This article examines union membership statistics for the period of voluntary unionism in 1984-85. It shows that large unions lost proportionally more members than small unions, that female-intensive unions did not lose a disporportionately high number of members, and that employer deduction of union fees was a key factor in membership retention.

\section{Introduction}

New Zealand's system of compulsory union membership has a long history as a politically contentious issue. This history is dealt with by Szakats (1972). Walsh (1983) and Howells (1983). Since 1936 a post-entry closed shop has prevailed with (since 1961) union membership being negotiated as part of the collective bargaining process. New Zealand unions, widely recognised as litigious rather than militant organisations, relied heavily on the guarantee of membership and revenue through the compulsion of the law. In 1984 in a radical move, the National Government abolished the post-entry closed shop system of union membership thus making union membership voluntary. The introduction of that change along with its initial impact is reported in Harbridge and Walsh (1985). In brief, the implementation of the voluntary unionism legislation on 1 February 1984 was met by a determination by trade unions to resist the change. Some unionists in the manufacturing sector took strike action against fellow workers who resigned from their union and industrial factors such as union organisation and strength were critical in determining just how many members defected from their unions.

In July 1984, the National Government was defeated by the Labour Party in a snap general election. Labour had as part of its election manifesto the statement that "Labour will provide for a system of union membership based on the principle of "unqualified preference" which recognises that those who gain should contribute to the cost of that gain" - in other words the restoration of what had become in practice compulsory unionism (New Zealand Labour Party, 1984). Not surprisingly Labour was supported organisationally and financially by the trade unions. Once in Government however, Labour moved slowly to implement its policy and only after concerted union pressure did the Government introduce (in December 1984) the Union Membership Bill into Parliament. The largely unchanged bill was passed into law in June 1985 and took effect from 1 July 1985 . The effect of the legislation was to require the insertion of a union membership clause into every existing and new award or collective agreement registered with the Arbitration Court. The clause obliged any adult worker covered by the agreement to join the appropriate union within 14 days of commencing employment, provided the worker had been asked to join. Each union benefiting from such a clause was required to hold a ballot of its members (only) before 31 December 1986 to confirm the retention of the union membership provision. Thereafter ballots were to be held every 3 years. The new provision forced unions that had previously been voluntary (such as the New Zealand Universities Technicians Union whose members had voted not to have compulsory union membership in 1980) to become compulsory, but taken overall, the change seemed to be introduced with surprisingly little opposition.

Industrial Relations Centre, Victoria University of Wellington. This research was supported by grant 87/86 from Victoria University's Internal Research Committee. The authors would like to thank the journal's referees and the Editor for their helpful comments. 
A system enabling exemption from union membership was also reintroduced. Applications for exemption from union membership are heard by the Union Membership Exemption Tribunal. Grounds for exemption are on the basis of conscience or other deeply held personal conviction. Before 1984 a similar system operated, yet only 1000 current employed workers were exempted from union membership. 'If the previous Conscientious Objection Committee's approach was seen as conservative then the approach of the new Tribunal must be seen as a "most liberal one" with exemptions being granted to the vast majority of applicants (Vranken, 1986).

Looking at the initial impact of voluntary unionism. Harbridge and Walsh have estimated that the overall initial level of resignations of workers from their unions was around the 5 percent mark. However, the degree of union agitation for a return to compulsory union membership indicated that losses may have been significantly greater than that level. This paper examines the changes in union membership levels from 31 December 1983 - the period immediately before the introduction of voluntary unionism - to 31 December $1985-6$ months after the return of compulsory union membership, and attempts to determine just how reliant on the law New Zealand unions have become for membership.

\section{Union membership returns}

This examination of changes to the levels of union membership relies upon the official returns made by unions to the Department of Labour (DoL). Section 187 of the Industrial Relations Act 1973 required unions to make an annual return of the total number of their members as at 31 December in each year. The Federation of Labour (FoL) also required affiliated unions to make a return so that it can levy its capitation fee on affiliated unions. Not surprisingly, the figures supplied to the DoL and the FoL are identical.

There are some general reservations about these statistics that should be considered. It is reasonably clear that these official statistics understate the true levels of union membership. Geare (1983) estimates that there are some 30000 union members who are excluded from these figures. Their exclusion results partly from genuine clerical error but also includes those unions who understate their membership to reduce their levy to the FoL - a practice described by Geare as "not that uncommon" (p. 81). In reality, the number excluded is certainly far greater than 30000 . The FoL when assessing its capitation fee, does not consider part-time and/or seasonal workers, yet many unions charge a reduced union fee for such workers. The New Zealand Workers Union, for example, has 13876 members according to its official return, yet has as many as $30000-40000$ different members during the height of the fruit-picking seasons (Harbridge, 1986). Many of those workers would be union members for just a few weeks of the year. Accordingly, many unions declare a union membership figure calculated on the union's total income from union fees, divided by the annual union fee. This is a sensible approach and one that has the (unofficial at least) blessing of FoL officials. It does however, mean that the official returns are unlikely to be accurate. However, the official statistics have been examined as they are the only primary sources of data available. Returns for years ending 31 December 1983, 1984, and 1985 have been compared (Department of Labour 1984, 1985, and 1986).

\section{Membership changes}

Registered private sector union membership peaked in New Zealand in 1983 with 527683 members recorded. The 1984 figures reveal a drop in membership of 7.9 percent to 485484 members. In 1985, the restoration of compulsory union membership saw a slight increase in the number of union members - to 490206 , yet this was still 7.1 percent fewer members than in 1983. The overall impact of the changes from compulsory to voluntary unionism and back again has been that unions have been unable to regain many of the members that chose to withdraw from their unions. Losses and gains have by no means been uniform with some unions actually gaining between 1983 and 1985 whereas others have been forced out of existence. It is not surprising that some unions did gain members as the private sector work force expanded by 8.6 percent during the same period, and it would be expected that union membership would have increased partly through that expansion. While not all of this growth would have been in the unionised labour force, a considerable proportion would have seen. Accordingly it is reasonable to assume that in the period of voluntary unionism the true levels 
Table 1: Membership change of unions with over 10000 members 1983 - 85

\begin{tabular}{lrrr}
\hline Union & \% Change & \% Change & \% Change \\
& $\mathbf{1 9 8 3 - 8 4}$ & $\mathbf{1 9 8 4 - 8 5}$ & $\mathbf{1 9 8 3 - 8 5}$ \\
& & & \\
\hline NZ Carpenters etc Union & -11.52 & +9.38 & -3.21 \\
NZ Bank Officers Union & 5.71 & +8.66 & +2.45 \\
Northern Clerical etc Union & -46.99 & +37.85 & +26.90 \\
Wgtn Clerical etc Union & -4.03 & +20.47 & +15.61 \\
NZ Electrical Union & +1.28 & -1.25 & +0.01 \\
NZ Engineering etc Union & 0 & -12.52 & -12.52 \\
NZ Meat Processors etc Union & +0.05 & -1.88 & -1.82 \\
Northern Hotel. Hospital etc Union & -0.36 & 0 & -0.36 \\
Wgtn Hotel. Hospital etc Union & +14.47 & -12.09 & +0.62 \\
NZ Labourers etc Union & +4.59 & -18.98 & -15.26 \\
Auck Local Authorities Officers Union & -13.56 & +8.28 & -6.40 \\
NZ Printing Union & -6.47 & -8.04 & -14.00 \\
NZ Workers Union & -19.31 & -18.39 & -34.15 \\
NZ Shop Employees Union & -5.36 & -39.13 & -42.39 \\
NZ Timber Industry Union & 0 & +0.03 & +0.03
\end{tabular}

Unions with more than 10000 members Unions with less than 10000 members All unions

$\begin{array}{rrr}-5.79 & -4.83 & -10.34 \\ -10.31 & +7.38 & -3.69 \\ -7.99 & +0.97 & -7.10\end{array}$

of unions losses are greater than the 7.1 percent figure quoted, as potential gains in union membership through the growth of the labour force were not achieved.

\section{Membership changes and union size}

New Zealand has a proliferation of small unions, with 87 unions having less than 200 members in 1983. The combined membership of these unions dropped from 6469 in 1983 to 5626 in 1984 - a decrease of 13 percent. Membership dropped further to a total of 5525 in 1985 . a total fall of 14.5 percent. Five unions in this category cancelled their registration during this period and this can be attributed in part to the abolition of compulsory unionism. Others failed to make a return in 1985 but an analysis of those small unions that did, reveals a very different pattern. There was a 8.5 percent loss in 1984 but a gain in 1985 bringing the overall loss to a mere 3.2 percent - less than half the average loss across all unions.

By comparison the 15 largest unions, those with over 10000 members each, lost members in both 1984 ( 5.8 percent) and 1985 ( 4.8 percent). Their overall membership loss between 1983 and 1985 was 10.3 percent. In Table 1 membership losses of unions with over 10000 members are compared with unions with less than 10000 members and with the membership loss for unions overall.

Only the New Zealand Bank Officers Union and the Wellington Clerical Workers Union increased significantly (by more than 1 percent) in size over that 2 year period. Six unions lost a significant number of members, ranging from a 12 percent loss from the Engineers Union to the 42 percent loss from the New Zealand Shop Employees and Related Trades Union, although that union lost only 5.4 percent of its membership in the first year that unionism was made voluntary. Despite having more resources because of their size, large unionswere among the least able to retain union membership in the face of change. This becomes clear when examining the results in Table 1. The domination of the large unions in the overall statistics is a consideration (these 15 unions accounted for 51 percent of all union members in the 1985 year) when the total losses are considered. The total loss over the 2 year period for unions with memberships less than 10000 was a comparatively small 3.69 percent. 


\section{Unions with predominantly women and part-time members}

It had been predicted that the unions most affected by voluntary unionism would be those unions with substantial female memberships. Former National Member of Parliament for Waipa, Marilyn Waring, told Parliament that voluntary unionism would have its greatest impact on female intensive unions which she described as the weaker unions seldom involved in disruption, while "stronger unions would become stronger and militant unions will be reinforced" (Hansard, 1983). The negative impact of voluntary unionism on women workers and unions was also predicted in detail by Clerical Workers Union organisers O'Connell, Gillespie and Tennet in a New Zealand Listener article (McTaggert, 1984).

To examine the impact of voluntary unionism on female intensive unions, 30 unions comprising predominantly women workers were examined. They included cleaners, clerical workers, dental assistants, early childhood workers, hotel workers, nurses and shop employees unions. Overall these unions decreased in union membership by 12 percent in 1984 but experienced a 5.5 percent recovery in 1985. The overall impact of voluntary unionism for unions with predominantly female members was a 7.2 percent decrease. Compared with the general decrease of 7.1 percent overall, female intensive unions lost no more members than other unions.

There were some significant exceptions to this overall trend. One union, the Early Childhood Workers Union, gained rather than lost members during this period - hardly a surprising phenomenon given that this was a relatively new union still in the early stages of recruiting its initial membership and that the union had yet to negotiate its first national award. Other exceptions were however surprising. The Canterbury Clerical Workers Union lost no members in 1984 and then actually gained some in 1985 and the Wellington Clerical Workers Union lost only 4 percent of its members in 1984 but by 1985 had gained 15.6 percent more members than it had in 1983. Other clerical workers unions suffered different fates however and lost substantial numbers of members. The Northern Clerical Workers Union, for example, lost 47 percent of its membership in 1984 and even after regaining many it was 26 percent down on its 1983 membership figure at the end of 1985.

Voluntary unionism had a major impact on another group of female intensive unions. Unions that represent workers engaged by self-employed professionals such as chartered accountants, lawyers, pharmacists, and dentists lost on average 35.7 percent of their membership in 1984 and still had 17 percent fewer members in 1985 than in 1983.

\section{Membership change and union recruitment and retention methods}

Union membership recruitment and retention is achieved by 2 methods - annual (or partannual) billing or regular (generally weekly) automatic deduction from wages by the employer. The deduction of union fees from wages has been the subject of collective bargaining and currently 280 awards ( 78 percent of all awards) contain a provision legally requiring all employers bound by the award to deduct union fees. Further to these awards, 395 registered second tier agreements (either voluntary collective agreements or composite agreements) contain a fee deduction provision. Section 16 of the Wages Protection Act had allowed an employer to deduct union fees from wages without the written consent of each individual worker if the relevant award or collective agreement contained a fee deduction provision. The Act was amended with effect from 1 June 1984 so that this provision was invalidated and each worker was required to sign individually that they agreed to the deduction of union fees from their wage. With the introduction of compulsory unionism in 1985 the Wages Protection Act was further amended to allow for the automatic deduction of union fees without the necessity to have each worker individually authorise their employer to comply with the award condition.

Of the 12 unions that lost proportionately the most members in 1984 , only 4 had automatic fee deduction clauses in their major awards and agreements.

Automatic fee deduction provisions were undoubtedly the major reason why some unions successfully retained their members while other unions lost heavily. One union that lost very substantially, yet had a fee deduction clause was the New Zealand Commercial Travellers and Sales Representatives Union which lost 70 percent of their members in 1984, but this was an unusual case. This union was established in the mid-1970s to represent a group of previously non-unionised workers. That establishment was not a response to the demands of those workers but rather was designed to avoid union coverage by the active storeworkers' unions. It is 
not surprising that this group of unwilling unionists should use the opportunity presented in 1984 to leave their union in large numbers.

Unions have made a significant push for fee deduction clauses in their awards over the last decade. However, not all were successful. Employers in the clerical industry repeatedly rejected union claims for a fee deduction provision in the award. In an attempt to persuade the employers assessors to the national clerical negotiations that fee deduction was a common practice, the Canterbury Clerical Workers Union was very active in obtaining voluntary collective agreements over union membership and fee deductions. As a result there are 139 such agreements in the Canterbury Industrial District covering clerical workers (Harbridge 1986). The existence of these agreements appears to be the main reason why the Canterbury Clerical Workers Union was able to maintain its membership level through the voluntary unionism period. The changes to the Wages Protection Act appear to have had limited impact and were widely ignored according to industry and union sources.

\section{Membership change and union affiliation to the Labour Party}

There were 91 unions or branches of unions affiliated to the Labour Party in 1985 on the basis of voluntary political affiliation. Because affiliation was not always undertaken on the same basis as union registration, it has been possible to examine the returns of only 78 of these affiliated unions. These unions lost a mere 2.5 percent of their membership by the end of 1984 . Compared with the overall average loss of 7.9 percent they fared well. In the next year however, the restoration of compulsory unionism saw a further drop in union membership. Taken over the 2 year period, affiliated unions lost 7.3 percent of their membership whereas the average loss taken across all unions was only 7.1 percent. The significance of these figures is discussed below.

\section{Discussion}

In this analysis of the growth and decline of union membership, it is necessary to attempt to separate factors related to changes in the structure of the workforce from legal changes to the system of union membership. The employment structure of the workforce since 1976 has changed in some distinctive ways. Certain occupational groups have grown significantly over the last decade. There has been growth in the service and finance sectors, the primary sector has remained stable and the secondary sector has declined. Union membership levels from 1976 to 1983, the last year of compulsory unionism, reflect the general trends in employment. Taken overall, unions representing manufacturing employees lost members. Some unions were vulnerable because of their reliance for members on only one factory or industry. For example, the Flourmills Employees Unions in Wellington. Timaru, Oamaru and Dunedin and Biscuit Manufacturing Unions in Christchurch and Otago/Southland became defunct when their mills and factories were closed down. One exception to this general trend was the New Zealand Engineers Union which grew from 43223 members in 1976 to 51446 in 1984 before dropping to 45000 in 1985.

The growth in the service sector was matched by the increased participation of women working both full-time and part-time. The number of full time women workers in the paid work force increased by 14 percent between 1976 and 1985. Over the same period, the number of parttime women workers increased by 42 percent $^{2}$. Occupations that employ mainly women often have more part-time work opportunties and this led to a direct increase in union membership in those occupations. Unions with a high proportion of women members working in the service sector grew significantly. The growth in some employment sectors brought an important increase to membership for some unions. For example the New Zealand Bank Officers Union, reflecting the growth in the finance industry, increased its membership by 55 percent between 1975 and 1983. The Wellington Cleaners Union, a service union with a high proportion of women members increased by 44 percent and the Wellington Hotel and Hospital Workers Union increased by 200 percent. This latter increase was due to both growth in the hospitality industry and the spread of part-time work. This meant that many union members had more than one job and consequently were belonging to different unions for each job. The 
growth of unions that represent many women and part-time employees was however checked by the introduction of voluntary unionism. The growth that had occurred in those occupations and industries between 1983 and 1985 is a likely explanation for the fact that the female intensive unions did not lose more heavily than the average union.

While unions have little control over the growth and decline of industry and its consequent impact on union membership numbers, they do have control over some organisational factors that will enable them to more easily recruit and retain members. This research identifies that the most critical of these factors is the automatic deduction of union fees from wages. Where automatic union fee deduction was mutually acceptable and the norm for workers and employers, unions had comparatively few recruitment and retention problems. Where union fees were paid by an annual billing system, unions had severe difficulties retaining and recruiting members. This is not to say that workers paying union fees annually were any more "anti-union" than workers paying fees weekly. Simply, an account for union fees that did not have to be paid could be expected to take low priority in the family budget. Budgetary rather than ideological motivation seems the most likely cause for some of the substantial losses some unions incurred.

A more difficult phenomenon to explain is the curious finding that officially many unions lost few members in the first year of voluntary unionism yet lost substantial numbers of members in the year that compulsory unionism was restored. There are 3 possible explanations offered here. First, it is possible that the official statistics are accurate and that what is reflected in the fall-off of union membership is simply the difficulty that unions started to experience in recruiting new members rather than any difficulty with retaining existing members. It is quite possible that many unions experienced no onslaught of resignations during the first few months of voluntary unionism yet found recruitment of new workers in an industry a significant problem. Second, unions may have decided to understate the extent of their membership losses in 1984, thus concealing from their union colleagues, employers and the Government, the true extent of the impact of the voluntary unionism legislation. If unions did conceal their true losses initially, why then did they reveal the true position in the next year? The answer is probably linked to the issue of capitation. Unions that officially denied substantial membership losses were still required to pay capitation fees to the FoL on their official (rather than reduced) membership. It is likely that the economics of affiliating at unrealistically high levels forced unions to review their approach. Third, unions, particularly those affiliated to the New Zealand Labour Party, were endeavouring to seek a legislative solution to their difficulties, by trying to persuade the newly elected Labour Government to restore compulsory unionism. Any new government is anxious not to implement unpopular policies and official union returns showing substantial defections from unions may have led to the Labour Government believing that voluntary unionism was popular with workers. This could have made Labour more likely to resist restoring compulsory unionism. In the event, the Government saw official statistics that probably did not accurately reflect the true levels of loss and compulsory unionism was legislatively reintroduced from 1 July 1985.

Finally, it is worth commenting on union size as a factor in the rate of membership defection during the period of voluntary unionism. Much is made of the fact that 66 percent of New Zealand unions have less than 1000 members. Indeed, the Government in the Labour Relations Act 1987 has decided that unions with less than 1000 members will have their registration cancelled after a period of time. This change was argued on the basis that small unions are ineffective and provide few member services while large unions are more effective and provide wider member service. The research reported here has identified that while a few small unions with less than 200 members were unable to cope and became defunct, the vast majority of these small unions lost a very small percentage of their members compared with large unions. In some way, an individual worker's decision to accept or reject union membership must be a reflection of the perceived effectiveness of that union to the worker. In this case, it is reasonable to assume that members of small unions were happy with the services given them by their unions. Accordingly, in view of the data presented, there may be no sound basis for legislating small unions out of existence.

The abolition of voluntary unionism in 1984 had different effects on different unions. Some lost substantial numbers of members while others lost few. It seems likely that the true level of losses are not revealed by the official statistics for the various reasons outlined. The restoration of compulsory unionism in 1985 again confirms that New Zealand unions are more litigious than militant in character. Their reliance on compulsory membership through the law must be of concern to union leaders given the National Party's commitment to restoring voluntary unionism. If unions are to withstand a further change to the law here then they will need to be 
better organised than they have been in the immediate past.

This research has indicated that those unions that had negotiated union fee deduction clauses in their collective agreements were better placed to withstand legislative changes to the system of union membership. The lesson to be learned by unions from the experience of 1984 and 1985 is that the negotiation of union fee deduction mechanisms with employers is the best method of ensuring that membership losses are minimised in the future. The lesson for a government hostile to unions is that making the deduction of union fees illegal would severely weaken New Zealand unions.

\section{References}

Department of Labour (1984, 1985, and 1986) Annual report of the Department of Labour for the year ended 31 March 1983 (1984 and 1985) Wellington. Government Printer.

Geare, A J (1983) The system of industrial relations in New Zealand Wellington, Butterworths. Hansard (1983) New Zealand parliamentary debates Vol 455, p 4491.

Harbridge, R and Walsh. P (1985) Legislation prohibiting the closed shop in New Zealand : its introduction and consequences Journal of industrial relations 27 (2): 191-206.

Harbridge, R (1986) Collective second tier bargaining in New Zealand New Zealand journal of business pp. 40-55.

Howells, J M (1983) For or against compulsory unionism? Recent ballots in New Zealand International labour review 122 (1): 95-110.

McTaggert, S (1984) "The boss bloody decides" New Zealand Listener 18 February, pp. 1314.

New Zealand Labour Party (1984) Industrial relations policy p 1.

Szakats, A (1972) Compulsory unionism : a strength or weakness? The New Zealand system compared with union security agreements in Great Britain and the United States Alberta law review, (Edmonton), 10: 313-342.

Vranken, M (1986) Union membership and the union membership exemption tribunal: a critical review Working Paper 9/86. Industrial Relations Centre, Victoria University of Wellington.

Walsh, P (1983) Union membership policy in New Zealand 1894 - 1982. In Brosnan, P (ed) Voluntary unionism Industrial Relations Centre, Victoria University of Wellington. 